PERAN PT SARANA MULTIGRIYA FINANSIAL DALAM LIKUIDITAS PEMBIAYAAN PERUMAHAN

Rayhan Mahatma Harikusuma ${ }^{1}$, Roby Syaiful Ubed ${ }^{2}$

Politeknik Keuangan Negara STAN

Email : rayhan.mahatma@gmail.com ${ }^{1}$

\begin{tabular}{l}
\hline INFORMASI ARTIKEL \\
\hline Diterima Pertama: \\
[08 Oktober 2020] \\
Revisi : \\
[10 November 2020] \\
Dinyatakan Diterima \\
[20 November 2020]
\end{tabular}

\section{KATA KUNCl:}

Badan Usaha Milik Negara, Penyertaan Modal Negara, Peran Sarana Multigriya Finansial

\section{ABSTRAK}

ultigriya Finansial is a state owned enterprise (BUMN), focused on helping out government to develop primary and secondary mortgage market. In general, SMF main role is providing long-term fund to mortgage loan (KPR) distribution agency (bank) so it's liquidity can be guaranteed. In order to strengthen and build up primary and secondary mortgage market, SMF contribute by offering financial assets securitization and loan facility. In 2018, SMF got government public service obligation to carry through funding provision by means of banking scheme on housing financing liquidity facility (FLPP).

Sarana Multigriya Finansial merupakan Badan Usaha Milik Negara yang membantu pemerintah dalam sektor pembangunan pasar pembiayaan sekunder dan primer. Secara garis besar, peran SMF adalah menyediakan dana jangka panjang bagi lembaga penyalur KPR sehingga likuiditas lembaga tersebut dapat terjaga. Untuk memperkuat dan membangun pasar primer dan sekunder maka SMF membantu dengan memberikan sekuritisasi aset keuangan dan pemberian pinjaman. Pada tahun 2018, SMF mendapatkan penugasan pemerintah untuk dapat membantu menyediakan dana pada porsi perbankan pada Fasilitas Likuiditas Pembiayaan Perumahan (FLPP) 
PERAN PT SARANA MULTIGRIYA FINANSIAL

DALAM LIKUIDITAS PEMBIAYAAN PERUMAHAN

Rayhan Mahatma Harikusuma ${ }^{1}$ dan Roby Syaiful Ubed $^{2}$

\section{PENDAHULUAN}

\subsection{Latar Belakang}

Negara Kesatuan Republik Indonesia merupakan salah satu negara kepulauan yang terletak di Asia Tenggara. Menurut data dari Badan Pusat Statistik, wilayah Negara Indonesia seluas $1.916 .862 \mathrm{~km}^{2}$ yang di dalam wilayah yang luas tersebut terdapat penduduk dengan jumlah 265 juta jiwa. Jumlah penduduk Indonesia diproyeksikan akan terus tumbuh dan saat ini Indonesia memasuki era bonus demografi, era ketika jumlah penduduk usia produktif lebih banyak daripada jumlah penduduk yang memiliki usia tidak produktif.

Sejalan dengan jumlah penduduk, maka jumlah kebutuhan yang dibutuhkan oleh masyarakat akan meningkat sesuai dengan peningkatan jumlah penduduk. Menurut Abraham Maslow, dalam makalahnya yang berjudul "A Theory of Human Motivation", terdapat lima tingkat kebutuhan dasar yang secara bertahap dibutuhkan oleh manusia. Kebutuhan fisiologis merupakan kebutuhan dasar yang harus dipenuhi lalu dilanjutkan kebutuhan akan rasa aman, rasa kasih sayang, penghargaan, dan pada tingkat terakhir kebutuhan aktualisasi diri. Kebutuhan fisiologis sering dikenal dengan sandang, pangan, dan papan. Salah satu kebutuhan dasar adalah papan, yang lebih dikenal dengan kebutuhan akan tempat tinggal. Kebutuhan tempat tinggal dapat didefinisikan dengan kebutuhan akan rumah. Menurut UndangUndang Nomor 1 Tahun 2011 tentang Perumahan dan Kawasan Permukiman, definisi rumah terdapat pada pasal 1 ayat 7 yang berbunyi "Rumah adalah bangunan gedung yang berfungsi sebagai tempat tinggal yang layak huni, sarana pembinaan keluarga, cerminan harkat dan martabat penghuninya, serta aset bagi pemiliknya." Pada tahun 2010, setelah dilakukan sensus penduduk di Indonesia oleh Badan Pusat Statistik, masih terdapat 13 juta rumah tangga yang belum memiliki rumah berdasarkan hak milik pribadi.

Di Indonesia, terdapat masalah dalam penyediaan sumber daya untuk mendukung kebutuhan tempat tinggal atau rumah. Terdapat kesenjangan untuk pemenuhan kebutuhan yang besar, terlebih dari sisi permintaan terhadap rumah yang diakibatkan oleh kurangnya kemampuan atau daya beli masyarakat. Hal ini terjadi karena masih banyaknya masyarakat yang memiliki penghasilan rendah yang kurang mampu untuk melakukan pemenuhan kebutuhan rumah khususnya Masyarakat
Indonesia Rich Journal, Vol. 1, No. 2, (2020), 73-90

Berpenghasilan Rendah (MBR) dengan penghasilan paling banyak Rp8.000.000,00 per bulan. Menurut survey BPS pada tahun 2019, rata-rata angsuran per bulan untuk KPR yang harus dibayarkan oleh masyarakat daerah perkotaan sebesar Rp1.827.053,00 sedangkan untuk pedesaan sebesar Rp1.013.902,00. Dari sisi perbankan sistem pendanaan untuk menyediakan rumah seperti Kredit Pemilikan Rumah (KPR) juga kurang berjalan secara maksimal karena sumber dana yang tersedia untuk pembiayaan KPR pada umumnya berjangka pendek (tabungan, deposito, giro, dan obligasi) namun masa angsuran KPR berjangka panjang sehingga (rata-rata 12 tahun) menimbulkan kesenjangan waktu yang berpengaruh pada likuiditas perbankan.

Melalui mekanisme pengelolaan kekayaan negara dipisahkan, pemerintah membantu untuk memenuhi kebutuhan rumah, sebagai salah satu tugas pemerintah, dengan membentuk suatu Badan Layanan Umum (BLU) yaitu Pusat Pembiayaan Perumahan (PPP) pada tahun 2010. Pemerintah menyalurkan dana bergulir yang bersumber dari Anggaran Pendapatan dan Belanja Negara (APBN) berupa subsidi Kredit Pemilikan Rumah (KPR) dengan menggunakan skema Fasilitas Likuiditas Pembiayaan Perumahan (FLPP) yang kemudian populer dengan sebutan KPR FLPP. Skema KPR ini memberikan bantuan kepada Masyarakat Berpenghasilan Rendah (MBR) secara tidak langsung melalui bank pelaksana. Bank pelaksana memerlukan likuiditas yang baik agar dapat memberikan kredit kepada masyarakat dengan syarat seperti rumah dengan harga terjangkau, suku bunga tetap, angsuran ringan dan memiliki jangka waktu panjang, serta uang muka yang ringan. Dengan FLPP, bank pelaksana dapat mendapatkan pinjaman dana dari PPDPP untuk menambah sumber dana berjangka panjang sehingga bank dapat mengurangi kesenjangan waktu pendanaan dan likuiditas perbankan.

Selain itu, pemerintah juga membentuk suatu Badan Usaha Milik Negara yang berperan untuk membantu penyediaan perumahan yaitu PT Sarana Multigriya Finansial (SMF). Menurut Undang-Undang Nomor 19 Tahun 2003 tentang Badan Usaha Milik Negara, badan usaha milik negara (BUMN) adalah badan usaha yang seluruh atau sebagian besar modalnya dimiliki oleh negara melalui penyertaan secara langsung yang berasal dari kekayaan negara yang dipisahkan. Pelaksanaan operasional serta pengawasan BUMN dilakukan oleh Kementerian 
PERAN PT SARANA MULTIGRIYA FINANSIAL DALAM LIKUIDITAS PEMBIAYAAN PERUMAHAN

Rayhan Mahatma Harikusuma ${ }^{1}$ dan Roby Syaiful Ubed $^{2}$

Keuangan c.q Direktorat Jenderal Kekayaan Negara selaku wakil pemerintah dalam pemegang saham pada perseroan.

Tugas SMF sebagaimana tercantum dalam Peraturan Presiden Nomor 1 tahun 2008 juncto 19 Tahun 2005, adalah membangun dan mengembangkan Pasar Pembiayaan Sekunder Perumahan (PPSP). Perusahaan tersebut membantu pemerintah untuk meringankan beban penyaluran dana melalui FLPP sehingga dapat mengurangi beban bank pelaksana untuk menyalurkan KPR.

Pembiayaan perumahan menjadi salah satu hal yang menarik untuk dibahas terutama terkait kebijakan pemerintah seperti FLPP dan pendirian BUMN PT SMF untuk menyelesaikan masalahmasalah yang ada pada negara berkembang seperti Indonesia. Berdasarkan hal tersebut, maka penulis menarik untuk melakukan penelitian peran lebih lanjut PT SMF dalam perannya untuk membantu likuiditas pembiayaan perumahan sehingga penulis memilih penelitian berjudul "PERAN PT SARANA MULTIGRIYA FINANSIAL (PERSERO) DALAM LIKUIDITAS PEMBIAYAAN PERUMAHAN"

\subsection{Ruang Lingkup Pembahasan}

Ruang lingkup penulisan ini hanya meliputi halhal yang berhubungan dengan peran $\mathrm{P}$ SMF dalam likuiditas pembiayaan perumahan, kendala-kendala yang ditemui dalam proses pelaksanaan, serta kesesuaian prosedur dengan ketentuan dan peraturan perundang-undangan, kemudian melakukan analisis berdasarkan data yang didapat.

\subsection{Tujuan Penulisan}

Tujuan yang ingin dicapai Penulis dalam menyusun tulisan ini adalah sebagai berikut:

1. Meneliti permasalahan yang timbul dari pembiayaan program KPR perumahan bersubsidi.

2. Meneliti peran pengelolaan kekayaan negara dipisahkan dalam mendukung salah satu program pemerintah di bidang pembiayaan perumahan.

3. Membahas peran PT SMF dalam proses pembiayaan perumahan yang dapat mengurangi beban fiskal dalam APBN

\section{KERANGKA TEORI}

\subsection{Konsep Kekayaan Negara Dipisahkan}

Regulasi terkait kekayaan negara dipisahkan diatur dalam Peraturan Menteri Keuangan Republik Indonesia Nomor 246/PMK.06/2016 tentang Penatausahaan Kekayaan Negara Dipisahkan. Pada peraturan tersebut, diatur definisi yaitu kekayaan
Indonesia Rich Journal, Vol. 1, No. 2, (2020), 73-90

negara yang berasal dari Anggaran Pendapatan dan Belanja Negara (APBN) dan/atau sumber lainnya yang diinvestasikan oleh pemerintah pusat secara jangka panjang dan berkelanjutan serta dikelola secara terpisah dari mekanisme APBN. Maksud dikelola secara terpisah dari mekanisme APBN adalah dikelola secara korporasi namun tetap mengutamakan kepentingan dan kesejahteraan rakyat.

Kewenangan pengelolaan kekayaan negara dipisahkan berada pada unit eselon 1 dibawah Kementerian Keuangan yaitu Direktorat Jenderal Kekayaan Negara yang dilaksanakan pada Direktorat Kekayaan Negara Dipisahkan. Menurut Peraturan Menteri Keuangan Nomor 184/PMK.01/2010 tentang Organisasi dan Tata Kerja Kementerian Keuangan, Direktorat Kekayaan Negara Dipisahkan bertugas merumuskan serta melaksanakan kebijakan standardisasi teknis di bidang kekayaan negara dipisahkan. Untuk mendukung tugas tersebut, Direktorat KND memiliki fungsi sebagai berikut:

a. Penyiapan perumusan kebijakan di bidang kekayaan negara dipisahkan.

b. Penyiapan pelaksanaan kebijakan di bidang kekayaan negara dipisahkan.

c. Penyiapan penyusunan norma, standar, prosedur, dan kriteria di bidang kekayaan negara dipisahkan; penyiapan pemberian bimbingan teknis dan ecaluasi di bidang kekayaan negara dipisahkan. Dan

d. Pelaksanaan urusan tata usaha direktorat.

Dalam bidang pengelolaan BUMN, Direktorat Kekayaan Negata Dipisahkan dapat mengevaluasi kinerja Badan Usaha Milik Negara untuk selanjutnya dapat dilakukan perubahan bentuk hukum atau usulan penyertaan modal negara. Peraturan Pemerintah Nomor 72 Tahun 2016 Tentang Perubahan atas Peraturan Pemerintah Nomor 44 Tahun 2005 tentang Tata Cara Penyertaan Modal Negara pada Badan Usaha Milik Negara dan Perseroan Terbatas mengatur tentang definisi penyertaan modal negara. Penyertaan Modal Negara merupakan pemisahan kekayaan negara dari APBN atau penetapan cadangan perusahaan atau sumber lain untuk dijadikan sebagai modal BUMN dan/atau Perseroan Terbatas lainnya, dan dikelola secara korporasi. Penyertaan Modal Negara merupakan sarana pemerintah dalam berinvestasi pada suatu BUMN atau Perseroan Terbatas yang mampu menghasilkan kepemilikan pemerintah atas suatu badan usaha. Penyertaan modal negara juga 
PERAN PT SARANA MULTIGRIYA FINANSIAL DALAM LIKUIDITAS PEMBIAYAAN PERUMAHAN

Rayhan Mahatma Harikusuma ${ }^{1}$ dan Roby Syaiful Ubed $^{2}$

merupakan sarana pemerintah untuk membantu keuangan suatu badan usaha agar dapat tetap menjalankan usahanya sesuai dengan proses bisnis atau penugasan yang diberikan oleh Pemerintah.

\subsection{Konsep Badan Usaha Milik Negara}

Regulasi mengenai Badan Usaha Milik Negara di Indonesia diatur dalam Undang-Undang Nomor 29 Tahun 2003 tentang Badan Usaha Milik Negara. Definisi BUMN didalam peraturan tersebut adalah perusahan yang sebagian besar modalnya dimiliki oleh pemerintah melalui penyertaan secara langsung yang berasal dari kekayaan negara yang dipisahkan. Sumber modal BUMN dapat berasar dari Anggaran Pendapatan dan Belanja Negara (APBN), kapitalisasi cadangan, dan sumber lainnya. Salah satu peraturan teknis terkait kekayaan negara dipisahkan yaitu Peraturan Menteri Keuangan Republik Indonesia Nomor 246/PMK.06/2016 tentang Penatausahaan Kekayaan Negara Dipisahkan mengatur lebih rinci mengenari BUMN atau perusahaan negara. Definisi perusahaan negara merupakan perusahaan yang berbentuk perseroan, perusahaan umum, dan perseroan terbatas yang seluruh atau sebagian modalnya dimiliki oleh negara, yang diwakili oleh kepemilikan pemerintah dalam perusahaan tersebut. Penyertaan Modal pada BUMN berdasarkan Peraturan Pemerintah Nomor 72 Tahun 2016 tentang Perubahan atas Peraturan Pemerintah Republik Indonesia Nomor 44 Tahun 2005 tentang Tata Cara Penyertaan Dan Penatausahaan Modal Negara Pada Badan Usaha Milik Negara dan Perseroan Terbatas bersumber dari Anggaran Pendapatan dan Belanja Negara, kapitalisasi cadangan, dan sumber lainnya. Melalui APBN, penyertaan modal dianggarkan pada tahun sebelum dilakukan penyertaan melalui mekanisme APBN lalu pada tahun berikutnya penyertaan modal tersebut diberikan kepada BUMN. Kapitalisasi cadangan merupakan modal yang berasal dari cadangan. Cadangan bisa berasal dari keuntungan atau laba yang seharusnya dibagikan kepada pemodal atau pemegang saham, namun keuntungan tersebut diberikan kepada BUMN untuk menjadi modal disetor tambahan. Penyertaan modal yang berasal dari sumber lainnya meliputi dana segar, barang milik negara, piutang negara pada BUMN atau Perseroan Terbatas, saham milik negara, dan aset negara lainnya. Setelah modal disetorkan atau diberikan kepada BUMN, modal tersebut dikelola oleh BUMN secara korporasi untuk mendapatkan keuntungan diluat mekanisme pengelolaan APBN.
Indonesia Rich Journal, Vol. 1, No. 2, (2020), 73-90

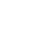

(a)

Bentuk Badan Usaha Milik Negara berdasarkan
Undang-Undang Nomor 19 Tahun 2003 tentang
BUMN yaitu perusahaan perseroan, perusahaan perseroan terbatas, dan perusahaan umum. Perusahaan perseroan atau persero merupakan BUMN dengan modal yang terbagi atas saham dengan kepemilikan seluruh atau minimal 51\% (lima puluh satu persen) dimiliki oleh negara. Bagi perusahaan perseroan terbuka, perusahaan telah melakukan penawaran umum atas sahamnya pada pasar modal sesuai dengan peraturan perundangundangan tentang pasar modal sehingga masyarakat dapat memiliki saham perusahaa tersebut. Bentuk lainnya adalah perusahaan umum atau perum yang keseluruhan modalnya dimiliki oleh negara dan tidak terbagi atas saham.

BUMN merupakan agen pemerintah yang berada pada sektor korporasi, maka lini bisnis BUMN ditentukan oleh pemerintah sesuai dengan bidang yang difokuskan pemerintah untuk dilakukan pembangunan. Sesuai dengan maksud dan tujuan pendirian BUMN yaitu memberikan sumbangan bagi perkembangan perekonomian dan penerimaan negara. Selain itu bumn juga diharuskan agar menyelenggarakan kemanfaatan umum dengan penyediaan barang dan jasa untuk menjadi perintis kegiatan yang belum dapat dilaksanakan sektor swasta dan korporasi.Penugasan pemerintah melalui BUMN dengan penyertaan modal didalamnya diharapkan mampu dikelola dengan baik sesuai dengan prinsip tata kelola perusahaan yang baik sehingga dapat menghasilkan nilai lebih bagi para pemangku kepentingan termasuk didalamnya pemerintah dan rakyat Indonesia.

\subsection{Konsep Pembiayaan Sekunder Perumahan}

Secara umum, konsep pembiayaan adalah penyediaan dana berdasarkan kewajiban oleh penyedia dana kepada pengguna dengan imbal hasil yang disepakati dan nantinya dikembalikan lagi kepada penyedia dana untuk membantu likuiditas pengguna dana. Menurut Kasmir (2012), Pembiayaan adalah penyediaan uang atau tagihan yang dipersamakan dengan itu, berdasarkan persetujuan atau kesepakatan antara Bank dengan pihak lain yang mewajibkan pihak yang dibiayai untuk mengembalikan uang atau tagihan tersebut setelah jangka waktu tertentu dengan imbalan atau bagi hasil. Pada pembiayaan sekunder perumahan, konsep yang diadopsi adalah penyediaan dana untuk membantu likuiditas suatu pengguna dana. Menurut 
PERAN PT SARANA MULTIGRIYA FINANSIAL DALAM LIKUIDITAS PEMBIAYAAN PERUMAHAN

Rayhan Mahatma Harikusuma ${ }^{1}$ dan Roby Syaiful Ubed $^{2}$

Peraturan Presiden Nomor 101 Tahun 2016 Tentang

Perubahan Kedua Atas Peraturan Presiden Nomor 19

Tahun 2005 Tentang Pembiayaan Sekunder Perumahan, Pembiayaan Sekunder Perumahan merupakan kegiatan penyaluran dana menengah dan/atau panjang kepada kreditur dengan melakukan transformasi aset yang tidak likuid menjadi likuid melalui pembelian aset keuangan dari kreditur lalu menerbitkan efek beragun aset.

Pasar pembiayaan sekunder memiliki tiga fungsi. Fungsi yang pertama adalah mengurangi kesenjangan akibat mismatch terhadap sumber pendanaan yang terjadi pada Lembaga Penyalur KPR baik perbankan maupun non perbankan. Lembaga penyalur KPR, membutuhkan dana untuk menjaga likuiditasnya karena menyalurkan KPR membutuhkan sumber aliran dana jangka menengah dan panjang sedangkan dana yang tersedia banyak yang berasal dari deposito nasabah yang pada jangka waktu pendek dapat diambil kembali oleh nasabah. Peran yang kedua adalah membantu melakukan sekuritisasi dan memperkuat pasar modal di suatu negara. Melalui efek beragun aset, suatu lembaga yang ditunjuk pemerintah untuk menerbitkan efek yang berupa surat utang atau surat partisipasi bersumber dari kumpulan piutang lembaga penyalur KPR. Lembaga yang menerbitkan efek beragun aset selanjutnya melakukan penawaran efek tersebut pada pasar modal. Pemerintah melakukan penunjukan suatu perusahaan yang dapat menerbitkan efek beragun aset dengan bentuk perseroan terbatas yang merupakan Badan Usaha Milik Negara. Dan yang terakhir adalah membantu menambahkan jangka waktu jatuh tempo pembayaran serta membuat inovasi baru dibidang pembiayaan sekunder untuk membantu masyarakat yang memiliki penghasilan rendah untuk mampu membeli rumah dengan jangka waktu panjang dan suku bunga tetap.

\section{METODE PENELITIAN}

\subsection{Jenis Data}

Data yang digunakan dalam membuat tulisan ini adalah data kualitatif dan data kuantitatif. Data kualitatif adalah data yang disajikan dalam bentuk kata verbal bukan angka atau bilangan sedangkan data kuantitatif adalah data yang disajikan dalam bentuk angka atau bilangan.

\subsection{Sumber Data}

Sumber data adalah subjek dari mana data dapat diperoleh. Dalam penelitian ini penulis menggunakan sumber data sekunder. Sumber data
Indonesia Rich Journal, Vol. 1, No. 2, (2020), 73-90

sekunder merupakan data yang diperoleh peneliti dari sumber yang sudah ada. Data sekunder diperoleh dari studi-studi yang telah ada sebelumnya atau yang diterbitkan oleh berbagai instansi.

\subsection{Teknik Pengumpulan Data}

Untuk memperoleh data sesuai dengan tujuan dalam tulisan ini, penulis menggunakan teknik studi kepustakaan. Studi kepustakaan adalah segala usaha yang dilakukan oleh peneliti untuk menghimpun informasi yang relevan dengan topik atau masalah yang akan atau sedang diteliti. Studi kepustakaan dalam tulisan ini dilakukan terhadap peraturanperaturan mengenai pembiayaan sekunder perumahan dan buku-buku yang dapat menambah informasi.

\section{HASIL PENELITIAN}

\subsection{Peran PT Sarana Multigriya Finansial (Persero)}

Sarana Multigriya Finansial didirikan oleh pemerintah untuk membangun pasar pembiayaan sekunder perumahan. Menurut laporan direksi perusahaan yang termuat pada laporan tahunan PT Sarana Multigriya Finansial tahun 2006 mengenai pendekatan untuk membangun pasar tersebut pada negara berkembang terdapat dua cara yaitu mendirikan lembaga pembiayaan sekunder perumahan terlebih dahulu atau mempersiapkan infrastruktur terlebih dahulu. Indonesia memilih menggunakan opsi pertama dengan mendirikan lembaga pembiayaan sekunder perumahan terlebih dahulu. Berdasarkan Peraturan Presiden Nomor 101 Tahun 2016 tentang Perubahan Kedua atas Peraturan Presiden Nomor 19 Tahun 2005 tentang Pembiayaan Sekunder Perumahan sebagai lembaga keuangan yang berhak melakukan proses pembiayaan sekunder perumahan, pemerintah mendirikan perusahaan pembiayaan sekunder perumahan. Perusahaan tersebut berbentuk perseroan terbatas dengan modal yang seluruhnya dimiliki oleh Pemerintah Republik Indonesia.

Membangun pasar pembiayaan sekunder perumahan dengan memilih opsi untuk mendirikan lembaga pembiayaan sekunder terlebih dahulu membutuhkan waktu yang lama untuk berkembang. SMF perlu melakukan pembangunan pasar primer terlebih dahulu untuk meningkatkan permintaan pada pasar sekunder perumahan. Oleh karena itu, SMF mendorong bertumbuhnya Kredit Pemilikan Rumah yang disalurkan oleh lembaga penyalur KPR. Permasalahan utama pada pasar primer tersebut adalah mengenai ketersediaan dana, terjadi mismatch penggunaan dana pada lembaga penyalur KPR. Sumber dana yang digunakan lembaga penyalur KPR seperti perbankan berasal dari dana dengan aliran yang pendek seperti dana deposito nasabah sedangkan perbankan membutuhkan dana dengan 
PERAN PT SARANA MULTIGRIYA FINANSIAL DALAM LIKUIDITAS PEMBIAYAAN PERUMAHAN

Rayhan Mahatma Harikusuma ${ }^{1}$ dan Roby Syaiful Ubed $^{2}$

aliran dana menengah dan panjang untuk membiayai KPR. Hal tersebut yang mendorong SMF untuk melakukan penyaluran pinjaman kepada lembaga penyalur KPR atau perbankan untuk menjaga likuiditas dan menumbuhkan pasar primer pembiayaan perumahan sehingga penyaluran KPR meningkat dan mempermudah kepemilikan rumah bagi masyarakat indonesia.

Program pembiayaan yang dilakukan oleh SMF terdapat dua skema, yang pertama adalah skema refinancing KPR dan skema repo KPR. Skema refinancing KPR dilakukan dengan memberikan sejumlah dana kepada lembaga penyalur KPR untuk membiayai kembali portofolio KPR. SMF memberikan dana sebagai gantinya lembaga penyalur memberikan jaminan berupa tagihan KPR dan hak agunannya sesuai dengan syarat dan kriteria yang ditentukan termasuk didalamnya apabila KPR yang dibayarkan oleh masyarakat kepada lembaga penyalur kurang lancar, maka SMF berhak untuk mendapatkan ganti oleh lembaga penyalur dengan KPR yang lancar. Pengembalian dana yang telah dipinjam oleh lembaga penyalur KPR dikembalikan dengan sejumlah bunga tetap selama jangka waktu program sebagai salah satu pendapatan SMF. Dengan program refinancing KPR diharapkan beban bunga yang ditanggung oleh lembaga penyalur KPR lebih rendah dari program pembiayaan sebelumnya sehingga jumlah penyaluran KPR kepada masyarakat meningkat. Program pembiayaan ini juga terdapat dengan sistem syariah. Program pembiayaan syariah menjanjikan skema pembayaran imbal hasil yang dibayarkan tiap bulan.

Lembaga penyalur KPR yang memenuhi syarat dapat mendapatkan bantuan pembiayaan dari SMF. Bentuk lembaga penyalur KPR tersebut dapat berupa perbankan atau non perbankan. SMF telah melakukan kerjasama penyaluran pembiayaan dengan perbankan baik berjenis bank umum maupun bank syariah. Bank umum tersebut dapat berupa Badan Usaha Milik Negara di sektor perbankan seperti Bank Tabungan Negara (BTN), Bank Negara Indonesia (BNI), atau perbankan swasta seperti Bank Central Asia (BCA). Untuk lebih memaksimalkan jangkauan pembiayaan, SMF juga melakukan kerjasama dengan Bank Pembangunan Daerah. Perbankan syariah juga mendapatkan pembiayaan melalui SMF dengan prinsip-prinsip syariah yang diawasi oleh dewan pengawas syariah yang dibentuk khusus oleh perusahaan. Diluar perbankan, SMF juga dapat melakukan kerjasama dengan perusahaan pembiayaan lain seperi MNC Finance.

Skema kedua adalah skema repo KPR. skema ini merupakan skema transaksi jual beli hak tagih KPR oleh SMF untuk jangka waktu tertentu dengan kewajiban lembaga penyalur KPR untuk membeli kembali atau mengganti hak tagih. Skema ini membantu likuiditas lembaga penyalur KPR dengan mengalihkan untuk jangka waktu tertentu hak tagih
Indonesia Rich Journal, Vol. 1, No. 2, (2020), 73-90

(1)

\author{
(1)
}

dengan ganti berupa dana yang diberikan oleh SMF, setelah jangka waktu perjanjian berakhir maka lembaga penyalur KPR wajib untuk membeli kembali kumpulan hak tagih yang sudah dialihkan sebelumnya dengan harga yang sudah ditentukan dalam perjanjian. Secara akuntansi masih tercatat dalam pencatatan pada neraca lembaga penyalur KPR namun untuk status hukum hak atas aset tagihan beralih kepada SMF, sehingga sistem ini dapat membantu lembaga penyalur KPR untuk sementara mendapatkan likuiditas atau mengurangi dana yang mengendap akibat penyaluran KPR.

Skema kedua adalah skema repo KPR. skema ini merupakan skema transaksi jual beli hak tagih KPR oleh SMF untuk jangka waktu tertentu dengan kewajiban lembaga penyalur KPR untuk membeli kembali atau mengganti hak tagih. Skema ini membantu likuiditas lembaga penyalur KPR dengan mengalihkan untuk jangka waktu tertentu hak tagih dengan ganti berupa dana yang diberikan oleh SMF, setelah jangka waktu perjanjian berakhir maka lembaga penyalur KPR wajib untuk membeli kembali kumpulan hak tagih yang sudah dialihkan sebelumnya dengan harga yang sudah ditentukan dalam perjanjian. Secara akuntansi masih tercatat dalam pencatatan pada neraca lembaga penyalur KPR namun untuk status hukum hak atas aset tagihan beralih kepada SMF, sehingga sistem ini dapat membantu lembaga penyalur KPR untuk sementara mendapatkan likuiditas atau mengurangi dana yang mengendap akibat penyaluran KPR.

SMF mendapatkan dana untuk menjalankan fasilitas pembiayaan tersebut melalui pasar modal dengan penerbitan obligasi korporasi melalui penawaran umum, medium term notes melalui tanpa melalui penawaran umum, dan sukuk. Untuk awal pembiayaan, SMF menggunakan kekuatan permodalan yang ada untuk mendanai pembiayaan. Setelah itu ditindaklanjuti dengan menerbitkan surat utang dengan jangka waktu menengah dan panjang yang dapat diperjualbelikan pada pasar modal dengan kewajiban membayar bunga pada periode tertentu dan pokok hutang. Struktur permodalan perusahaan dituntut untuk memiliki kinerja keuangan yang stabil dan tumbuh agar dapat menghasilkan dana yang sesuai untuk menutup beban dari pemberian pembiayaan KPR kepada lembaga penyalur KPR. Tabel dibawah merupakan hasil penerbitan obligasi korporasi yang berisi jangka waktu, tingkat bunga, dan jumlah yang diterbitkan pada tahun 2018 dan masih belum jatuh tempo hingga tahun 2021.

Hingga tahun 2018 jumlah pembiayaan yang disalurkan kepada Bank Umum, Bank Pembangunan Daerah, dan Multi Finance membukukan jumlah outstanding pinjaman sebanyak Rp 15,37 triliun. Kenaikan jumlah outstanding pinjaman sebesar 38,84\% dibandingkan posisi pada tahun 2017 dengan 
PERAN PT SARANA MULTIGRIYA FINANSIAL DALAM LIKUIDITAS PEMBIAYAAN PERUMAHAN

Rayhan Mahatma Harikusuma ${ }^{1}$ dan Roby Syaiful Ubed $^{2}$

jumlah debitur yang meningkat pada angka 17,31\% menjadi sejumlah 546.495 debitur. Untuk mengimbangi hal tersebut, perusahaan juga harus mencetak obligasi untuk menjaga likuiditas perusahaan. Jumlah obligasi yang dikeluarkan oleh perusahaan juga mengalami tren kenaikan dari tahun ke tahun sejak tahun 2014 hingga 2019. Sesuai dengan ketentuan maka SMF harus tetap menjaga rasio aset lancar terhadap liabilitas lancar sebesar $1: 1$, serta rasio aktiva produktif dengan utang paling rendah sebesar 0,8:1. Keuntungan perusahaan dalam melakukan pembiayaan ini didapat dari margin bunga hasil pinjaman oleh lembaga penyalur KPR. SMF memberikan bunga untuk pinjaman KPR komersial sebesar $12 \%-14 \%$ sedangkan untuk memperoleh pendanaan dari penerbitan obligasi, SMF mengeluarkan cost of fund rata-rata dibawah $10 \%$.

Selain melalui obligasi, pendanaan Sarana Multigriya Finansial dapat melalui medium term notes yang diterbitkan oleh perusahaan selama jangka waktu tertentu dengan bunga tetap. Walaupun penerbitan medium term notes tidak sebanyak obligasi, tercatat perusahaan telah menerbitkan medium term notes sebanyak 8 kali untuk membantu sumber pendanaan SMF agar tetap dapat melakukan penyaluran pembiayaan.

Dampak pembiayaan SMF bagi penyalur KPR yang utama adalah terbentuknya pasar primer pembiayaan perumahan kuat, efektif, dan efisien. Dengan pembiayaan oleh SMF diharapkan lembaga penyalur KPR mendapatkan dana jangka menengah dan jangka panjang sehingga menjaga likuiditas dan mengembangkan kemampuan penyaluran lembaga penyalur KPR. Kapasitas penyaluran KPR baik secara nominal dan jumlah diharapkan mampu meningkat karena telah berkurangnya masalah mismatch funding yang terjadi pada lembaga penyaluran KPR. Di sisi lain, program pembiayaan SMF memiliki standar atau syarat khusus bagi lembaga penyalur agar dapat menggunakan fasilitas pembiayaan ini. Dengan demikian, maka secara tidak langsung, program pembiayaan yang dilakukan oleh SMF mendorong penerbitan KPR yang memiliki standardisasi tinggi untuk bisa dilakukan sekuritisasi di kemudian hari serta mendorong skema KPR yang memiliki dampak yang lebih baik bagi masyarakat untuk dapat memiliki rumah atas nama pribadi.

Peran SMF selanjutnya adalah melakukan sekuritisasi KPR. Menurut Peraturan Presiden Nomor 101 Tahun 2016 tentang Perubahan Kedua Atas Peraturan Presiden Nomor 19 Tahun 2005 tentang Pembiayaan Sekunder Perumahan, Sekuritisasi adalah transformasi aset yang tidak likuid menjadi likud dengan cara pembelian aset keuangan dari kreditur asal dan penerbitan efek beragun aset. Aset keuangan yang dimiliki oleh lembaga penyalur KPR ditransformasikan terlebih dahulu menjadi efek untuk dapat dilakukan penjualan di pasar modal sehingga
Indonesia Rich Journal, Vol. 1, No. 2, (2020), 73-90

(1)

dana yang didapatkan dari investor di pasar modal diteruskan oleh SMF kepada lembaga penyalur KPR. Perjanjian penerbitan dilakukan oleh lembaga penyalur KPR dengan SMF lalu selaku lembaga keuangan yang dapat menerbitkan efek, SMF melakukan pendaftaran pada Otoritas Jasa Keuangan. Setelah Otoritas Jasa Keuangan menyatakan pernyataan efektif, maka akta jual beli dan akta cessie untuk menandakan pengalihan piutang dari lembaga penyalur KPR kepada SMF dilakukan dan SMF dapat melakukan penerbitan Efek di pasar modal.

Perkembangan skema penerbitan efek yang dilakukan oleh SMF dengan sekuritisasi yang masih menggunakan skema Kontrak Investasi Kolektif-Efek Beragun Aset (KIK-EBA) yang dimulai pada tahun 2009. Hingga pada tahun 2014, SMF telah melakukan atau memfasilitasi 7 kali transaksi sekuritisasi dengan skema KIK-EBA. Pada tahun 2014, skema transaksi sekuritisasi oleh SMF berubah dengan skema Efek Beragun Aset Surat Partisipasi (EBA-SP). Untuk Dana yang telah terkumpul di pasar modal karena pembelian EBA-SP oleh investor untuk selanjutnya diteruskan kepada lembaga penyalur KPR melalui bank kustodian. Dengan skema sekuritisasi, lembaga penyalur KPR mengubah aset keuangan piutang yang tidak likuid menjadi dana segar yang likuid dan siap digunakan kembali untuk melakukan penyaluran KPR.

Program realisasi Efek Beragunan Aset yang tercatat pada bursa dimulai oleh SMF pada tahun 2009. Seiring berkembangnya zaman, pada tahun 2014 terbit peraturan OJK mengenai Efek Beragunan Aset Surat Partisipasi yang mengatur tentang skema penerbitan dan hingga saat ini hanya diterbitkan oleh SMF. EBA-SP menjadi peluang investasi bagi investor dengan imbal hasil yang terdiri dari EBA-SP Arus Kas Tetap dan EBA-SP Arus Kas Tidak Tetap. EBA-SP arus kas tetap memberikan investor penghasilan tertentu seperti pada pemegang efek bersifat hutang. Untuk EBA-SP arus kas tidak tetap, investor diberikan penghasilan tidak tentu seeperti pada pemegang efek bersifat ekuitas. Pemegang efek atau investor dapat menjual tanpa harus menunggu tenor EBA-SP. Risiko yang dihasilkan oleh efek ini berupa fluktuasi harga pada pasar sekunder yang diakibatkan perubahan tingkat suku bunga dan pelunasan KPR yang lebih awal sehingga mempengaruhi yield yang diterima investor. Tabel dibawah adalah contoh EBA-SP yang telah diterbitkan oleh SMF.

Aset piutang yang telah dilakukan sekuritisasi oleh SMF pada tahun 2018 sebesar Rp10,16 triliun yang berarti tumbuh sebesar 24,5\% dibandingkan pencapaian tahun 2017 sebesar Rp8,6 triliun. Berdasarkan histori laporan keuangan perusahaan, kenaikan signifikan terhadap nilai sekuritisasi yang dilakukan SMF terjadi pada tahun 
PERAN PT SARANA MULTIGRIYA FINANSIAL DALAM LIKUIDITAS PEMBIAYAAN PERUMAHAN

Rayhan Mahatma Harikusuma ${ }^{1}$ dan Roby Syaiful Ubed $^{2}$

2015 yang naik sebesar Rp4,16 triliun menjadi Rp5,66 triliun. Selain sebagai penerbit EBA-SP, SMF juga menjadi koordinator global dalam transaksi sekuritisasi. Sebagai koordinator global, SMF bertanggung jawab untuk melakukan koordinasi secara keseluruhan terhadap proses transaksi termasuk sebagai penata sekuritisasi yang menyiapkan dan mengatur seluruh transaksi sekuritisasi, melakukan penunjukan para pihak yang terlibat dalam transaksi, menjadi penghubung antara instansi dengan lembaga pemerintah terkait, dan bertanggung jawab terhadap kinerja pihak-pihak penunjang transaksi sekuritisasi KPR. SMF juga dapat menjadi investor yang membeli efek hasil penerbitan serta menjadi pendukung kredit.

Pendapatan sekuritisasi yang didapatkan SMF berasal dari jasa komisi pendukung kredit, jasa penata sekuritisasi, dan jasa pendidikan dan pelatihan tentang sekuritisasi aset. Pada tahun 2019, pendapatan sekuritisasi mencatatkan nominal Rp4,8 Milyar. SMF juga mendapatkan keuntungan dari hasil investasi yang ditempatkan pada beberapa efek hasil sekuritisasi.

Manfaat yang ditimbulkan dengan adanya sekuritisasi aset yang dilakukan oleh SMF bagi penyalur KPR antara lain mengurangi mismatch sumber pendanaan antara sumber pendanaan jangka pendek dengan pendanaan KPR yang memerlukan pendanaan jangka panjang. Lembaga penyalur KPR juga mendapatkan diversifikasi sumber dana jangka panjang selain obligasi korporasi dan sistem pembiayaan lain. Keuntungan yang didapat dari sekuritisasi bagi lembaga penyalur KPR berasal dari fee based income dan bukan margin tingkat suku bunga. Maka keuntungan ini dapat meningkatkan kemampuan lembaga penyalur KPR untuk memproduksi pendanaan KPR.

Bagi investor yang berada di Pasar Modal, investor akan mendapatkan alternatif produk investasi dengan basis portofolio aset sehingga tingkat risiko cenderung lebih rendah dibandingkan produk investasi lain. Penerbitan EBA-SP memiliki standar yang tinggi sehingga produk investasi mendapatkan peringkat yang baik oleh pemeringkat efek indonesia (pefindo) yaitu idAAA. Bagi pasar modal, tentunya dapat meningkatkan dan menumbuhkan lingkungan investasi dengan produk investasi yang beragam bagi investor sehingga memperkuat lingkungan pasar pembiayaan sekunder perumahan.

\subsection{Peran PT Sarana Multigriya Finansial (Persero) Dalam Mengurangi Beban Fiskal APBN}

Selaku perusahaan dengan misi khusus (Special Mission Vehicle) Kementerian Keuangan untuk melaksanakan tugas pembangunan, SMF telah membantu untuk menurunkan beban fiskal pemerintah dalam pembiayaan KPR FLPP dengan mengurangi porsi penyediaan dana pemerintah.
Indonesia Rich Journal, Vol. 1, No. 2, (2020), 73-90

Melalui Badan Layanan Umum Pusat Pengelolaan Dana Pembiayaan Perumahan (PPDPP) di bawah Kementerian Pekerjaan Umum dan Perumahan Rakyat, pemerintah membuat kebijakan dengan melakukan penyediaan dana murah jangka panjang untuk KPR program FLPP dengan porsi dana 90:10 atau disebut dengan metode blended financing. Lembaga penyalur KPR seperti perbankan dapat melakukan pinjaman dana kepada PPDPP untuk mendapatkan sumber dana murah jangka menengah dan panjang agar dapat menyalurkan KPR program FLPP dengan porsi $90 \%$ bersumber dari APBN Pemerintah dengan bunga pinjaman sebesar $0,5 \%$. Untuk sisa kebutuhan dana untuk menyalurkan KPR FLPP sejumlah $10 \%$, perbankan dapat melakukan pencairan dana secara mandiri baik melalui penerbitan obligasi perusahaan lembaga penyalur KPR atau fasilitas pendanaan lain yang tersedia. Segmentasi pasar untuk penyaluran KPR FLPP dari sisi perbankan merupakan pasar dengan risiko kegagalan tinggi namun tingkat pengembalian atau return yang dihasilkan rendah. Dibandingkan dengan penyaluran KPR properti komersial dengan suku bunga rata-rata mencapai $10 \%$ dan risiko yang dihadapi lebih kecil untuk gagal bayar. Namun dengan porsi 90:10 lembaga penyalur KPR masih mendapatkan keuntungan apabila menyaluran KPR FLPP dengan $10 \%$ dana yang berasal dari pendanaan dengan beban bunga 9,272\% (rata-rata bunga obligasi korporasi).

Bagi pemerintah, hal ini memberatkan sisi belanja fiskal negara. Pemerintah dituntut untuk menyediakan dana dengan jumlah yang besar untuk ditempatkan pada BLU PPDPP yang setiap tahun meningkat akibat porsi pendanaan yang tinggi dengan tingkat kecepatan perputaran dana yang lama akibat jangka waktu KPR FLPP selama 15-20 tahun. Menurut data dari laporan keuangan pemerintah pusat tahun 2018, dana bergulir yang ditempatkan pada BLU PPDPP mencapai Rp29.463.190.892.831,00, dibandingkan dengan penempatan dana bergulir pada BLU lain, PPDPP merupakan BLU dengan total akumulasi dana bergulir paling besar. Sistem pengelolaan keuangan BLU tidak dapat melakukan pengembangan dana atau leveraging sehingga total penyaluran dana kepada lembaga penyalur KPR sama dengan total dana yang didapat dari alokasi APBN pemerintah.

Pada tahun 2018, beban fiskal pemerintah dapat dikurangi dengan pengurangan porsi pendanaan dalam skema KPR FLPP. Porsi pendanaan dalam skema KPR FLPP berkurang dengan perbandingan $75: 25$. Pemerintah hanya menyediakan porsi dana sebesar $75 \%$ sedangkan sisa dana $25 \%$ merupakan dana yang berasal dari lembaga penyalur KPR atau perbankan. Hal ini dapat terwujud berkat peran SMF yang ikut dalam skema pendanaan KPR FLPP. SMF masuk menjadi sumber pendanaaan bagi lembaga penyalur KPR untuk mendapatkan dana sisa yang 
PERAN PT SARANA MULTIGRIYA FINANSIAL DALAM LIKUIDITAS PEMBIAYAAN PERUMAHAN

Rayhan Mahatma Harikusuma ${ }^{1}$ dan Roby Syaiful Ubed $^{2}$

digunakan untuk menyalurkan KPR FLPP dengan menyediakan pinjaman kepada lembaga penyalur KPR dengan cost of fund yang terjangkau sehingga dapat memberikan keuntungan bagi lembaga penyalur KPR.

SMF membantu dalam penyediaan dana porsi perbankan dengan suku bunga pinjaman yang dikenakan pada angka 4,45\% per tahun selama jangka waktu KPR FLPP. Keuntungan perusahaan yang dihasilkan dari margin bunga antara bunga penyaluran KPR dengan bunga pinjaman dibandingkan dengan porsi sebelumnya mengalami penurunan. Pada Skema 90:10 diasumsikan jumlah penyaluran KPR FLPP oleh perbankan sebesar Rp100,00, maka pemerintah menyediakan dana dengan jumlah dana sebesar Rp90,00 dengan tingkat bunga pinjaman sebesar $0.5 \%$ sedangkan perbankan menyediakan dana sebesar Rp10,00 yang keseluruhan dana dapat berasal dari modal perbankan atau melalui pinjaman dengan menerbitkan obligasi. Apabila keseluruhan modal perbankan didapat dari pinjaman, maka bunga pinjaman berkisar 9,272\%. Pada skema 90:10 pendapatan bersih perbankan dengan bunga pinjaman $9,272 \%$ beserta beban lainnya mendapatkan persentase $4,644 \%$ terhadap porsi pendanaan perbankan sehingga menghasilkan keuntungan sebesar Rp0,464.

Dengan asumsi jumlah penyaluran KPR FLPP yang sama, pada skema 75:25 persentase pendapatan bersih perbankan mengalami penurunan menjadi sebesar $1,417 \%$ terhadap porsi pinjaman perbankan. Dilihat dari nominal pendapatan, skema 75:25 dengan bantuan suku bunga pinjaman 4,45\% mendapatkan keuntungan bersih perbankan yang menurun sebesar Rp0,110 menjadi Rp0,354. Penurunan ini diimbangi dengan kenaikan pendanaan dari porsi perbankan sehingga relatif tidak terlalu jatuh sehingga perbankan dapat tetap tertarik untuk melaksanakan penyaluran dana KPR melalui program FLPP.

SMF sebagai Special Mission Vehicle yang menjadi agen pembangunan pemerintah harus dapat menggantikan peran pemerintah dalam porsi pendanaan KPR FLPP. Secara bertahap, proporsi pemerintah dalam pendanaan KPR FLPP harus dikurangi dan digantikan oleh SMF. Hal tersebut dapat mengurangi beban fiskal yang ditanggung oleh pemerintah. Untuk tahap selanjutnya, skenario proporsi pendanaan diharuskan menjadi 50:50 yang dapat dilakukan dengan peran SMF yang menyediakan pinjaman dengan beban bunga pinjaman yang dikenakan kepada debitur sebesar $2,5 \%$. Dengan asumsi jumlah penyaluran yang sama pada skenario sebelumnya, penurunan persentase pendapatan bersih perbankan terhadap pinjaman turun menjadi 0,683\% namun secara angka nominal, pendapatan bersih perbankan turun menjadi Rp0,342
Indonesia Rich Journal, Vol. 1, No. 2, (2020), 73-90

(1)
tidak jauh dengan nominal angka pendapatan bersih
pada skenario 75:25.

Sejak dimulainya skema pendanaan yang baru dengan dukungan SMF pada bulan Agustus 2018, SMF tercatat telah menyalurkan dana sebanyak Rp946 Milyar hingga akhir tahun 2018 yang terdiri dari 28.932 debitur. Pada tahun 2019 jumlah penyaluran dana khusus untuk pembiayaan KPR FLPP mengalami kenaikan signifikan hingga menjadi sebesar Rp2,8 Triliun dengan suku bunga pinjaman yang sama dengan tahun sebelumnya yaitu $4,45 \%$.

Opsi untuk mengurangi beban fiskal pemerintah secara langsung menambah berat beban perusahaan. Untuk memberikan bunga pinjaman sebesar 2,5\% dalam jangka waktu yang panjang, perusahaan memerlukan likuiditas yang baik. Obligasi korporasi yang diterbitkan oleh SMF memiliki cost of fund yang tinggi rata-rata sebesar $6 \%-8 \%$ sedangkan keuntungan bunga pinjaman yang disediakan sebesar 2,5\% sehingga SMF tidak akan mendapatkan margin keuntungan dari penerbitan obligasi. Opsi lain yang dapat dilakukan adalah dengan sekuritisasi, namun untuk saat ini, tagihan piutang KPR FLPP belum dapat dilakukan sekuritisasi oleh SMF karena lembaga penyalur KPR belum dapat memenuhi syarat-syarat yang ditentukan. Lembaga penyalur KPR harus mampu meningkatkan kualitas penyaluran dana FLPP namun tetap sesuai dengan ketentuan pemerintah. Kualitas penyaluran dana KPR FLPP oleh lembaga penyalur harus ditingkatkan sehingga SMF dapat melakukan sekuritisasi terhadap piutang tagihan KPR FLPP. Dengan sekuritisasi, sudah seharusnya lembaga penyalur KPR dapat meningkatkan penyediaan perumahan bagi Masyarakat Berpenghasilan Rendah dengan skema KPR FLPP.

\subsection{Penyertaan Modal Negara Untuk Memaksimalkan Peran PT Sarana Multigriya Finansial}

Dalam melaksanakan penugasan pemerintah sebagai Special Mission Vehicle SMF memerlukan suntikan dana yang berasal dari Penyertaan Modal Negara atau PMN. Tambahan tugas dari pemerintah untuk membantu penyediaan dana KPR FLPP tentunya dapat mengganggu likuiditas dan keuangan perusahaan. Keuntungan perusahaan dari penyediaan dana pinjaman KPR Komersial dan penerbitan Efek Beragun Aset tidak mampu menyediakan likuiditas yang cukup bagi perusahaan untuk menyalurkan pinjaman program KPR FLPP. Tanpa adanya Penyertaan Modal Negara, kemampuan SMF dalam kontribusi untuk mendukung program pemerintah dalam kepemiikan rumah akan berkurang. Skema porsi 50:50 untuk pendanaan KPR FLPP akan sulit terwujud. Selain itu, Penyertaan Modal Negara juga dibutuhkan untuk menjaga struktur permodalan perusahaan sehingga mendapatkan peringkat tinggi untuk dapat 
PERAN PT SARANA MULTIGRIYA FINANSIAL DALAM LIKUIDITAS PEMBIAYAAN PERUMAHAN

Rayhan Mahatma Harikusuma ${ }^{1}$ dan Roby Syaiful Ubed ${ }^{2}$

menghasilkan obligasi dengan peringkat yang dapat dipercaya oleh investor. Peringkat yang baik mendorong para investor dan kreditur untuk memberikan pinjaman modal sehingga aliran dana dari pasar modal dapat diteruskan ke lembaga penyalur KPR untuk memfasilitasi pembiayaan perumahan. Bila struktur permodalan tidak dijaga, kemampuan memperoleh sumber dana akan berkurang karena untuk mitigasi risiko diperlukan rasio permodalan terhadap utang yang harus dijaga dengan besar tidak lebih dari 4 kali. Pada sektor riil, pertumbuhan pembangunan perumahan dapat berkurang karena kurangnya sumber dana untuk membantu likuiditas lembaga penyalur KPR.

Penyertaan Modal Negara yang ditempatkan pada SMF dilakukan secara rutin setiap tahunnya untuk menjaga kinerja keuangan perusahaan. Sejak berdirinya perusahaan, Pemerintah berupaya untuk menambah jumlah modal disetor melalui Penyertaan Modal Negara. Modal disetor awal perusahaan sebesar Rp1 Triliun telah bertambah hingga pada tahun 2019 menjadi sebesar Rp6,8 Triliun. Namun pada tahun 2019, nominal tambahan yang dialokasikan untuk Penyertaan Modal Negara mengalami penurunan hingga menjadi Rp800 Milyar. $\mathrm{Hal}$ ini dapat mengganggu kinerja perusahaan terutama dalam penyaluran pinjaman KPR walaupun tidak terlalu signifikan.

Dengan tambahan Penyertaan Modal Negara setiap tahunnya, jumlah modal disetor perusahaan meningkat sehingga dana investasi pemerintah yang berada di perusahaan meningkat. Namun kenaikan investasi tersebut sejalan dengan keuntungan atau manfaat yang diterima pemerintah. Salah satu manfaat langsung yang dapat oleh pemerintah selaku investor berupa dividen. Dividen yang dibagikan dapat menambah anggaran pendapatan pada APBN pemerintah. Selain dividen, pemerintah mendapatkan pendapatan pajak yang berasal dari perusahaan. Pajak yang dibayarkan adalah pajak penghasilan. Setiap tahun baik dividen maupun pajak penghasilan mengalami tren kenaikan. Dividen yang dibagikan berasal dari laba bersih perusahaan. Tidak setiap tahun dibagikan dividen seperti pada tahun 2014-2016 walaupun perusahaan mencatatkan laba. Pembagian dividen tidak dilakukan dengan pertimbangan untuk menambah kemampuan perusahaan sehingga diharapkan peningkatan bisnis terjadi. Pada tahun 2017 hingga 2019, perusahaan melakukan pembagian dividen yang seluruhnya dibagikan kepada pemerintah selaku investor tunggal.

Pajak penghasilan yang dibayarkan oleh perusahaan kepada pemerintah pada tahun 2014 hingga tahun 2019 memiliki tren peningkatan walaupun sempat mencatat penurunan pada tahun 2015. Hal ini mencerminkan kemampuan perusahaan untuk mencetak pendapatan dengan beban yang minimal sehingga menghasilkan laba yang maksimal.
Indonesia Rich Journal, Vol. 1, No. 2, (2020), 73-90 (1)

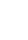

Peningkatan pembayaran pajak mengindikasikan
kemampuan operasi perusahaan yang semakin baik tiap tahunnya, segmentasi pasar tempat perusahaan melakukan bisnis mengalami perkembangan sehingga perusahaan mampu menghasilkan pendapatan yang tinggi.

Manfaat yang didapatkan pemerintah secara tidak langsung adalah berkembangnya pasar pembiayaan perumahan di Indonesia, baik pada pasar pembiayaan primer maupun pasar pembiayaan sekunder. Hal ini ditandai dengan meningkatnya jumlah pinjaman yang disalurkan oleh perusahaan. Tiap tahun jumlah yang disalurkan oleh SMF kepada lembaga penyalur perbankan dan non-perbankan mengalami peningkatan khususnya untuk program refinancing kredit pemilikan rumah. Dengan peningkatan jumlah penyaluran pinjaman, kemampuan lembaga penyalur KPR untuk menyediakan dana masyarakat semakin meningkat. Masyarakat semakin mudah memiliki rumah dengan bantuan pendanaan yang meningkat.

Kenaikan jumlah penyaluran pinjaman tiap tahunnya mengindikasikan kemampuan perusahaan yang semakin meningkat tiap tahunnya. Dibandingkan dengan jumlah modal disetor, perusahaan mampu mengubah jumlah modal yang ada dengan penyaluran pinjaman yang lebih banyak. Rasio perbandingan antara jumlah modal dengan jumlah penyaluran sempat menurun pada tahun 2016, namun tren peningkatan tetap terjadi hingga tahun 2019. Jumlah pinjaman yang dihitung dalam rasio tersebut termasuk jumlah pinjaman untuk penyaluran KPR program FLPP dengan suku bunga 4,45\% dengan jumlah penyaluran Rp 2,8 Triliun pada tahun 2019, KPR komersial yang kumpulan tagihan KPR tersebut belum dilakukan sekuritisasi dengan suku bunga 7,98\%-8,95\% per tahun dengan jumlah Rp 106 Milyar, dan pinjaman subordinasi sebesar Rp 6 Triliun dengan suku bunga pinjaman $8,97 \%$ per tahun.

Suntikan dana yang berasal dari pemerintah tetap dibutuhkan oleh SMF, namun dengan kemampuan perusahaan untuk melakukan leverage atau mengembangkan output dari sumber dana yang tersedia, beban fiskal yang ditanggung oleh pemerintah tidak terlalu besar. Dalam sektor pembangunan perumahan, khususnya dari sisi pembiayaan sekunder, jika dibandingkan untuk mengalokasikan dana dan disisihkan untuk ditambahkan ke dalam alokasi dana bergulir pada BLU PPDPP untuk KPR FLPP, lebih baik pemerintah melakukan penyisihan dana untuk dialokasikan ke dalam Penyertaan Modal Negara pada perusahaan SMF. BLU PPDPP tersebut hanya bisa menyalurkan jumlah yang sesuai anggaran yang diberikan oleh pemerintah, sedangkan SMF memiliki kemampuan untuk menggandakan dana tersebut sehingga dapat menyalurkan lebih dari yang dana yang diberikan pemerintah. 
PERAN PT SARANA MULTIGRIYA FINANSIAL DALAM LIKUIDITAS PEMBIAYAAN PERUMAHAN

Rayhan Mahatma Harikusuma ${ }^{1}$ dan Roby Syaiful Ubed $^{2}$

Idealnya porsi pemerintah pendanaan untuk bantuan KPR FLPP semakin lama semakin berkurang sehingga beban fiskal pemerintah dapat dikurangi. Penambahan porsi perbankan untuk penyaluran dana FLPP memang dapat memberatkan lembaga penyalur KPR, namun melalui PT Sarana Multigriya Finansial, pemerintah secara tidak langsung dapat membantu mengurangi beban lembaga penyalur KPR namun tidak menambah berat beban fiskal pemerintah. Secara bertahap alokasi anggaran untuk dana bergulir pembiayaan KPR FLPP dapat dialihkan menjadi dana untuk Penyertaan Modal Negara pada SMF. Hal ini tidak hanya berfungsi sebagai penguat modal perusahaan dana tersebut juga berfungsi sebagai katalis pemerintah untuk membangun pasar pembiayaan primer dan sekunder perumahan. Dengan berkembanganya pasar pembiayaan perumahan maka rakyat indonesia semakin mudah untuk dapat memiliki rumah sendiri dan tugas pemerintah untuk memenuhi kebutuhan dasar rakyatnya terpenuhi.

3.4. Hipotesis peran PT Sarana Multigriya Finansial

dalam skema pembiayaan Tabungan
Perumahan Rakyat (TAPERA)

Pada tahun 2020, Pemerintah Republik Indonesia menyelenggarakan skema baru dalam pembiayaan perumahan yang bertujuan untuk penyediaan perumahan bagi Masyarakat Berpenghasilan Rendah dengan skema gotong royong antar warga negara. Skema Tabungan Perumahan Rakyat atau TAPERA tersebut berdasarkan peraturan perundang-undangan yaitu Undang-Undang Nomor 4 Tahun 2016 tentang Tabungan Perumahan Rakyat. Definisi Tabungan Perumahan Rakyat terdapat pada peraturan perundang-undangan tersebut yang mengatakan bahwa Tabungan Perumahan Rakyat adalah penyimpanan yang dilakukan oleh peserta secara periodik dalam jangka waktu tertentu yang hanya dapat dimanfaatkan untuk pembiayaan perumahan dan/atau dikembalikan berikut hasil pemupukannya setelah kepesertaan berakhir. Peraturan penyelenggaraan Tapera disahkan pada tanggal 20 Mei 2020 oleh Presiden Republik Indonesia dengan dikeluarkannya Peraturan Pemerintah Nomor 25 Tahun 2020 tentang Penyelenggaraan Tabungan Perumahan Rakyat.

Pengelolaan Tapera dalam peraturan pemerintah tersebut meliputi pengerahan dana tapera, pemupukan dana, dan pemanfaatan dana Tapera yang dikoordinasikan oleh Badan Pengelola Tapera (BP Tapera) sekaligus selaku regulator dalam skema dana Tapera. Pengerahan dana Tapera merupakan proses pengumpulan dana dari peserta Tapera. Peserta tersebut merupakan pekerja dan pekerja mandiri yang memiliki penghasilan sebesar upah minimun agar dapat menjadi peserta Tapera. Besaran simpanan yang wajib dibayarkan untuk tetap
Indonesia Rich Journal, Vol. 1, No. 2, (2020), 73-90

menjadi peserta ditetapkan berdasarkan Peraturan Presiden yaitu sebesar 3\% dari gaji atau upah dan penghasilan yang ditanggung bersama oleh pemberi kerja sebesar 0,5\% dan pekerja sebesar 2,5\%. Prinsip kepesertaan tapera adalah prinsip gotong royong antara semua peserta sebagai solusi untuk mengatasi defisit perumahan (backlog) dan membantu Masyarakat Berpenghasilan Rendah untuk dapat memiliki rumah. Peserta Tapera mendapatkan manfaat dari iuran simpanan wajib tersebut berupa pemanfaatan dana untuk kepemilikan, pembangunan, dan perbaikan rumah serta hasil pemupukan dana yang diberikan saat peserta tidak lagi memenuhi syarat menjadi peserta sebagai contoh pensiun. Bagi masyarakat dengan kelas penghasilan tinggi, manfaat yang didapatkan hanya sebatas hasil pemupukan dana dan tidak berhak untuk menggunakan fasilitas pembiayaan perumahan. Dana tersebut disimpan dalam suatu rekening dan peserta berhak untuk memperoleh unit penyertaan investasi dari hasil pembayaran simpanan tersebut. Setiap hari bursa, bank kustodian wajib untuk menghitung nilai aktiva bersih hasil dari pengelolaan unit penyertaan investasi tersebut.

Pemupukan dana tapera dilakukan oleh manajer investasi yang bekerja sama dengan bank kustodian untuk meningkatkan nilai dana tapera dengan menempatkan pada instrumen investasi dalam negeri yang sudah diatur dalam peraturan perundangundangan. Manajer investasi tersebut ditunjuk oleh BP Tapera berdasarkan peraturan yang dibuat oleh BP Tapera dan dapat ditunjuk lebih dari satu manajer investasi, sedangkan untuk bank kustodian yang berfungsi sebagai jasa penitipan efek hanya ditunjuk satu bank kustodian. Dalam melaksanakan pemupukan dana tersebut, manajer investasi berhak mendapatkan imbal hasil atas kinerjanya dengan tetap mempertimbangkan asas efisiensi untuk penyediaan dana murah jangka panjang.

Pemanfaatan dana tapera meliputi penggunaan dana untuk pembiayaan yang terkait dengan perumahan dan dapat digunakan oleh peserta dengan kriteria tertentu. Pemanfaatan dana dalam bentuk pembiayaan perumahan meliputi pembiayaan untuk kepemilikan rumah, pembangunan rumah, dan perbaikan rumah. Pembiayaan tersebut disalurkan melalui perbankan atau lembaga pembiayaan yang ditunjuk oleh BP Tapera dan bertanggung jawab kepada BP Tapera dalam hal pelaporan pelaksanaan penyaluran pembiayaan. Kriteria bagi peserta yang dapat menggunakan manfaat pembiayaan perumahan sebagai berikut :

a. Mempunyai paling singkat 12 bulan untuk masa kepesertaaan;

b. Golongan Masyarakat Berpenghasilan Rendah;

c. Belum memiliki rumah; dan/atau 
PERAN PT SARANA MULTIGRIYA FINANSIAL DALAM LIKUIDITAS PEMBIAYAAN PERUMAHAN

Rayhan Mahatma Harikusuma ${ }^{1}$ dan Roby Syaiful Ubed $^{2}$

d. Menggunakan manfaat pembiayaan perumahan untuk kepemilikan atau perbaikan rumah pertama.

Skema Tapera diatur sedemikian rupa sehingga dalam pelaksanaannya memperhatikan prinsip pemisahan kewenangan, efisien, keterbukaan, dan pembagian risiko. Pemisahan kewenangan dilakukan secara terpisah oleh stakeholder dalam proses pengelolaan dana Tapera. Selaku regulator dan pengawas program dilaksanakan oleh BP Tapera. Untuk pengawas dalam investasi dana dilakukan oleh Otoritas Jasa Keuangan, serta Pelaksana yang memuat peran manajer investasi, bank kustodian, dan lembaga pembiayaan. Dengan demikian, maka suatu perusahaan atau badan usaha tidak dapat menjadi peran ganda selaku manajer investasi dan bank kustodian atau manajer investasi dan lembaga pembiayaan. Prinsip efisien mempertimbangkan penggunaan infrastruktur atau lembaga yang sudah berjalan yaitu Bapertarum yang asetnya dilebur dan dijadikan sebagai aset dan modal awal untuk BP Tapera. Prinsip keterbukaan dilakukan dengan laporan hasil investasi yang diberikan kepada nasabah peserta tapera serta instruksi BP Tapera terhadap para pemangku kepentingan yang dituangkan dalam kontrak. Pembagian risiko terjadi sebagai akibat dari pemisahan kewenangan sehingga setiap lembaga memegang risiko sesuai dengan fungsinya.

Sarana Multigriya Finansial selaku BUMN yang berjalan dalam lini bisnis pembiayaan untuk sektor perumahan dapat berkontribusi dalam skema Tapera pada proses pemanfaatan atau pemupukan dana Tapera. Pada proses pemanfaatan dana, SMF dapat berperan sebagai lembaga pembiayaan yang menyalurkan dana Tapera untuk membantu peserta membangun, memperbaiki, dan memiliki rumah. Pertimbangan SMF dapat masuk dalam alur tersebut adalah pengalaman yang telah dimiliki perusahaan terkait dengan penyaluran pinjaman yang telah lama menjadi fokus bisnisnya. Dengan pengalaman yang telah banyak, maka diharapkan penyaluran pinjaman tersebut dapat secara tepat menuju ke sasaran yang diharapkan. Selain itu, mempertimbangkan kemampuan leverage perusahaan, SMF dapat menggandakan dana Tapera untuk disalurkan walaupun dengan kriteria penyaluran yang sudah ditentukan dalam peraturan perundang-undangan terkait perumahan dan permukiman bagi masyarakat berpenghasilan rendah.

Peran lain yang dapat dikontribusikan oleh SMF adalah dalam proses pemupukan dana Tapera sebagai manajer investasi. Sebagai manajer investasi, SMF dapat menempatkan dana yang dikelola dalam instrumen investasi dalam bidang perumahan dengan salah satu contoh EBA-SP. Selain itu, fee manajer investasi yang ditanggung akan menjadi sumber pendapatan bagi SMF yang nantinya akan
Indonesia Rich Journal, Vol. 1, No. 2, (2020), 73-90

(n)

dikembalikan kembali untuk bidang pembiayaan perumahan sehingga dapat mengurangi tantangan dalam biaya pengelolaan manajer investasi dan menambah efektifitas pengelolaan dana Tapera.

Pembaharuan program pemerintah dalam mendukung kepemilikan rumah bagi masyarakat Indonesia diharapkan terus dapat bersinergi antara satu program dengan program yang lain sehingga dapat menambah efektifitas program tersebut. Pembentukan SMF selaku BUMN diharapkan tidak hanya melakukan tugas utamanya dalam membangun pasar pembiayaan pemerintah namun juga ikut dalam menyukseskan program pemerintah dengan menjadi jembatan agar program-program pemerintah di bidang pembiayaan perumahan dapat bersinergi satu sama lain dan menghasilkan tingkat efektifitas dan efisien tinggi.

\section{SIMPULAN DAN SARAN}

\subsection{Simpulan}

Setelah penulis melakukan pembahasan atas peran PT Sarana Multigriya Finansial dapat disimpulkan sebagai berikut:

1. PT Sarana Multigriya Finansial berperan untuk memajukan pasar pembiayaan perumahan pada pasar primer dan pasar sekunder. Untuk membangun pasar sekunder pembiayaan, dibutuhkan pasar pembiayaan primer yang kuat terlebih dahulu. Pada pasar primer, SMF melakukan penyaluran pinjaman langsung kepada masyarakat dengan suku bunga di bawah lembaga penyaluran KPR perbankan atau non perbankan. Masyarakat yang dapat melakukan pinjaman langsung kepada SMF harus memenuhi syarat-syarat tertentu. Pada pasar pembiayaan sekunder, SMF berperan membangun pasar pembiayaan sekunder dengan melakukan penyaluran pinjaman kepada lembaga penyalur KPR, melakukan sekuritisasi terhadap tagihan KPR yang berada pada lembaga penyalur.

2. KPR, dan menyediakan jasa pendidikan dan pelatihan untuk meningkatkan standar Kredit Pemilikan Rumah.

3. Sumber dana SMF dalam melakukan penyaluran pinjaman bersumber dari obligasi yang diterbitkan oleh perusahaan, medium term notes, dan penerbitan sukuk syariah perusahaan.

4. Program pembiayaan yang dilakukan SMF untuk menyalurkan pinjaman terdiri dari 2 program yaitu program refinancing dan program repo KPR. Program refinancing memiliki skema pendanaan kepada lembaga penyalur KPR dengan cara memberikan sejumlah dana dengan jaminan hak tagih terhadap KPR untuk membiayai portofolio KPR. Hak tagih dan agunan yang dijaminkan oleh lembaga penyalur KPR harus memiliki standar pelunasan yang tinggi 
PERAN PT SARANA MULTIGRIYA FINANSIAL DALAM LIKUIDITAS PEMBIAYAAN PERUMAHAN

Rayhan Mahatma Harikusuma ${ }^{1}$ dan Roby Syaiful Ubed $^{2}$

sehingga risiko tidak tertagih kecil. Sedangkan skema repo KPR dilakukan dengan membeli hak tagih untuk jangka waktu tertentu dengan kewajiban lembaga penyalur KPR untuk membeli kembali hak tagih tersebut. Kedua skema pembiayaan tersebut memiliki bunga tetap selama jangka waktu perjanjian.

5. Peran SMF selanjutnya dalam pasar pembiayaan perumahan adalah melakukan sekuritisasi terhadap aset keuangan lembaga penyalur KPR. sekuritisasi mengubah tagihan KPR yang merupakan aset non likuid menjadi likuid dalam bentuk Efek Beragun Aset yang dapat diperdagangkan di pasar modal. Dengan demikian maka lembaga penyalur KPR mendapatkan dana segar yang dapat digunakan untuk menambah program penyaluran KPR. Peran lain dalam sekuritisasi yaitu SMF menjadi Koordinator Global yang mengatur transaksi efek mulai dari penerbitan hingga dana sampai ke lembaga penyalur KPR, penata sekuritas (arranger). Penerbit EBA-SP, dan pendukung kredit. Selain itu, SMF juga dituntut juga untuk menjadi investor dalam efek yang diterbitkan untuk memperkuat pasar pembiayaan.

6. PT Sarana Multigriya Finansial juga melakukan pembiayaan syariah. Pembiayaan syariah merupakan program pendanaan bagi penyalur KPR iB dengan agunan berupa hak tagih KPR iB. Program pembiayaan syariah menjanjikan pembayaran imbal hasil yang dilakukan setiap bulan. Pengawasan program pembiayaan syariah dilakukan oleh dewan pengawas syariah yang dibentuk khusus.

7. SMF mendukung program pemerintah dalam KPR Program FLPP dengan cara membantu menyediakan dana untuk porsi perbankan. Di mulai pada tahun 2018, porsi pendanaan pemerintah untuk KPR FLPP dari semula $90 \%$ dapat diturunkan menjadi $75 \%$. Sisa $25 \%$ porsi perbankan dibantu dengan menyediakan pembiayaan dengan suku bunga 4,45\% per tahun hingga jangka waktu KPR selesai. Porsi pendanaan dapat lebih diturunkan lagi menjadi $50 \%$ namun SMF harus menyediakan pembiayaan dengan suku bunga maksimal 2,5\% agar para lembaga penyalur KPR tetap tertarik untuk mengikuti program KPR FLPP.

Untuk mendukung peran Sarana Multigriya Finansial dibutuhkan Penyertaan Modal Negara yang tiap tahun disetorkan kepada Sarana Multigriya Finansial. Manfaat penambahan PMN bagi perusahaan antara lain:

1. Meningkatkan kinerja PT Sarana Multigriya Finansial dalam penyaluran dana ke Pasar Pembiayaan Primer Perumahan sehingga dapat mendukung program pemerintah yang
Indonesia Rich Journal, Vol. 1, No. 2, (2020), 73-90

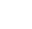

mewujudkan ketersediaan rumah dengan harga

2. Mendorong pergerakan sektor riil di bidang perumahan seperti membuka lapangan kerja, menurunkan angka kemiskinan, dan memberikan multiplier effect terhadap pertumbuhan ekonomi.

3. Memperkuat struktur permodalan perusahaan sehingga meningkatkan kemampuan perusahaan dalam menjalankan fungsi sebagai fasilitas likuiditas dan guarantor.

4. Mendukung penurunan porsi pemerintah dalam KPR Program FLPP.

Selama berdirinya perusahaan, PT Sarana Multigriya Finansial terlah memberikan manfaat bagi para pemangku kepentingan berupa:

1. Bagi pemerintah selaku pemegang saham, perusahaan telah memberikan deviden yang tiap tahun meningkat. Selain itu SMF telah memberikan kontribusi kepada negara berupa pajak penghasilan. Dalam mendukung program pemerintah, SMF telah memberikan bantuan untuk mengurangi beban fiskal pemerintah dalam KPR Program FLPP dengan mengurangi porsi pemerintah pada KPR Program FLPP.

2. Bagi investor yang berada di pasar modal, SMF telah memberikan variasi investasi baik melalui obligasi perusahaan maupun efek hasil sekuritisasi yang diterbitkan oleh SMF. Baik obligasi maupun EBA-SP memiliki peringkat terbaik dengan tenor panjang sehingga risiko yang dimiliki lebih minimal dan aman. Imbal hasil dari kedua instrumen investasi tersebut juga menarik dan investor secara langsung dapat berkontribusi pada pengembangan sektor riil perumahan.

3. Bagi lembaga penyalur KPR, masalah mismatch funding akibat kesenjangan ketersediaan dana antara sumber dana jangka pendek, menendah, dan panjang dapat teratasi melalui pembiayaan yang disalurkan oleh SMF. Selain itu likuiditas dan kinerja keuangan lembaga penyalur KPR dapat meningkat sehingga dapat menyalurkan lebih banyak KPR kepada masyarakat. Diversifikasi sumber pendanaan melalui sekuritisasi sehingga dapat memperoleh dana dari pasar modal. Secara tidak langsung telah meningkatkan kriteria atau kualitas KPR.

Dalam program terbaru yang diluncurkan oleh pemerintah di bidang pembiayaan perumahan yaitu Dana Tabungan Perumahan Rakyat (Tapera), SMF dapat berkontribusi dengan perannya menjadi lembaga penyalur pembiayaan dalam proses pemanfaatan dana atau menjadi manajer investasi dalam proses pemupukan dana.

\subsection{Saran}

Saran yang dapat penulis berikan terkait dengan hasil penelitian peran PT Sarana Multigriya Finansial 
PERAN PT SARANA MULTIGRIYA FINANSIAL DALAM LIKUIDITAS PEMBIAYAAN PERUMAHAN

Rayhan Mahatma Harikusuma ${ }^{1}$ dan Roby Syaiful Ubed $^{2}$

dalam likuiditas pembiayaan perumahan adalah sebagai berikut:

1. Pemerintah sebaiknya terus melakukan tambahan modal disetor kepada perusahaan PT Sarana Multigriya Finansial setiap tahunnya untuk memperkuat struktur permodalan perusahaan sehingga peran perusahaan dalam memperkuat pasar pembiayaan dan membantu pemerintah untuk dapat memberikan pinjaman kepada pihak lembaga penyalur KPR sebesar 2,5\% pada KPR Program FLPP terwujud dan beban fiskal pemerintah (Porsi Pemerintah) dapat semakin berkurang dan digantikan perannya oleh SMF.

2. Kebijakan pemerintah yang dibuat dalam mewujudkan ketersediaan rumah bagi masyarakat sebaiknya menggunakan peran SMF terlebih selaku satu-satunya BUMN yang berada pada lini bisnis pembiayaan sekunder sehingga lebih mengembangkan pasar yang ada.

3. Beban fiskal pemerintah dapat dikurangi dengan secara bertahap dengan mengalihkan dana bergulir yang dinvestasikan pemerintah pada BLU PPDPP kepada SMF mempertimbangkan pengelolaan keuangan yang ada, pada BLU tidak dapat melakukan leverage pada sumber pendanaan yang ada sedangkan SMF selaku perusahaan korporasi berbentuk perseroan terbatas memiliki kemampuan leverage sehingga dapat mengembangkan dana yang telah investasikan pemerintah dilihat dari rasio penyaluran pinjaman terhadap modal disetor yang cenderung meningkat pada setiap tahun pemberian Penyertaan Modal Negara.

4. Dalam skema Tapera, SMF dapat mengambil peran menjadi lembaga penyaluran dana, mempertimbangkan pengalaman di bidang penyaluran pembiayaan.

5. Peran lain SMF dalam Skema Tapera adalah menjadi manajer investasi yang melakukan pemupukan Dana Tapera dengan menempatkan dana kelolaan tersebut ke dalam instrumen investasi yang dapat mengembangkan pasar sekunder pembiayaan perumahan (EBA Ritel, EBA-SP, dan produk lain di bidang pembiayaan perumahan). Selain itu, mempertimbangkan fee manajer investasi yang dapat menjadi pendapatan SMF sehingga memperkuat struktur perusahaan.
Indonesia Rich Journal, Vol. 1, No. 2, (2020), 73-90

\section{DAFTAR PUSTAKA}

Keown, Arthur J. Jhon D Martin. William Petty. David F Scott. 2011. Manajemen Keuangan: Prinsip dan Penerapan, edisi kesepuluh. Jakarta: Indeks.

Kasmir, Jakfar. 2017. Studi Kelayakan Bisnis Edisi Revisi. Depok: Kencana

PT Sarana Multigriya Finansial (Persero). 2006. Laporan Tahunan 2006. Jakarta:PT Sarana Multigriya Finansial (Persero)

2014. Laporan Tahunan 2014 "Mencapai Pertumbuhan Yang Signifikan". Jakarta:PT Sarana Multigriya Finansial (Persero)

2015. Laporan Tahunan 2015 "Mendorong Pertumbuhan Ke Dasawarsa Berikutnya". Jakarta:PT Sarana Multigriya Finansial (Persero) 2016. Laporan Tahunan 2016 "Mengembangkan Strategi Baru Pembiayaan Perumahan". Jakarta:PT Sarana Multigriya Finansial (Persero)

2017. Laporan Tahunan 2017 "Optimis dan Fokus Dalam Meningkatkan Pembiayaan Perumahan di Masa Depan". Jakarta:PT Sarana Multigriya Finansial (Persero)

2018. Laporan Tahunan 2018 "Meraih Peluang Dengan Sinergi". Jakarta:PT Sarana Multigriya Finansial (Persero)

2019. Laporan Keuangan 2019. Jakarta:PT Sarana Multigriya Finansial (Persero)

Pemerintah Republik Indonesia. 2014. Laporan Keuangan Pemerintah Pusat 2014. Jakarta: Pemerintah Republik Indonesia 2015. Laporan Keuangan Pemerintah Pusat 2015. Jakarta: Pemerintah Republik Indonesia

2016. Laporan Keuangan Pemerintah Pusat 2016. Jakarta: Pemerintah Republik Indonesia

2017. Laporan Keuangan Pemerintah Pusat 2017. Jakarta: Pemerintah Republik Indonesia

2018. Laporan Keuangan Pemerintah Pusat 2018. Jakarta: Pemerintah Republik Indonesia

Pusat Pengelolaan Dana Pembiayaan Perumahan. 2018. Laporan Kinerja 2018. Jakarta:Pusat Pengelolaan Dana Pembiayan Perumahan 2016. Griya Sejahtera: Mari Dukung TAPERA Solusi Atasi Persoalan Pembiayaan Perumahan. Jakarta:Pusat Pengelolaan Dana Pembiayaan Perumahan

Badan Pusat Statistik. 2020. Statistik Indonesia 2020. Jakarta: Badan Pusat Statistik 
PERAN PT SARANA MULTIGRIYA FINANSIAL

DALAM LIKUIDITAS PEMBIAYAAN PERUMAHAN

Rayhan Mahatma Harikusuma ${ }^{1}$ dan Roby Syaiful Ubed $^{2}$

Rosa, Yulianda. Sri Sulasmi, Yuri Hermawan Prasetyo.2018. Pengembangan Model Penyediaan dan Pembiayaan Perumahan Bagi Masyarakat Berpenghasilan Rendah (MBR). Sub Kegiatan II: Model Sistem Housing Career. Jakarta:Pusat Litbang Perumahan dan Pemukiman

Mangeswuri, Dewi Restu. (2016). Kebijakan Pembiayaan Perumahan Melalui Fasilitas Likuiditas Pembiayaan Perumahan (FLPP), Jakarta: Pusat Penelitian Badan Keahlian Dewan Setjen DPR RI, Bidang Ekonomi dan Kebijakan Publik

Leong, Chung Chee. 2014. The Case Of A Secondary Mortgage Corporation In Malaysia. Malaysia: Cagamas Berhad

Direktorat Jenderal Anggaran Kementerian Keuangan. 2015. Peranan APBN Dalam Mengatasi Backlog Perumahan Bagi Masyarakat Berpenghasilan Rendah (MBR). Jakarta: Direktorat Jenderal Anggaran

Pemerintah Republik Indonesia. 2013.UndangUndang Republik Indonesia Nomor 19 Tahun 2003 Tentang Badan Usaha Milik Negara. Jakarta:Sekretariat Negara 2016.Undang-Undang Republik Indonesia Nomor 4 Tahun 2016 Tentang Tabungan Perumahan Negara. Jakarta:Sekretariat Negara 2010. Peraturan Menteri Keuangan Nomor 184/PMK.01/2010 tentang Organisasi dan Tata Kerja Kementerian Keuangan. Jakarta:Sekretariat Negara . 2016. Peraturan Menteri Keuangan Nomor 246/PMK.06/2016 tentang Penatausahaan Kekayaan Negara Dipisahkan. Jakarta:Sekretariat Negara 2010. Peraturan Menteri Keuangan Nomor 184/PMK.01/2010 tentang Organisasi dan Tata Kerja Kementerian Keuangan. Jakarta:Sekretariat Negara . 2005. Peraturan Pemerintah Republik Indonesia Nomor 5 Tahun 2005 Tentang Penyertaan Modal Negara Republik Indonesia untuk Pendirian Perusahaan Perseroan (Persero) Di Bidang Pembiayaan Sekunder Perumahan. Jakarta: Sekretariat Negara

2020. Peraturan Pemerintah Republik Indonesia Nomor 25 Tahun 2020 Tentang Penyelenggaraan Tapera. Jakarta: Sekretariat Negara 2011. Peraturan Presiden Republik Indonesia Nomor 75 Tahun 2011 Tentang Perubahan Atas Peraturan Pemerintah Nomor 5 Tahun 2005 Tentang Penyertaan Modal Negara Republik Indonesia untuk Pendirian Perusahaan Perseroan (Persero) Di

\section{.}

Indonesia Rich Journal, Vol. 1, No. 2, (2020), 73-90

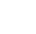


PERAN PT SARANA MULTIGRIYA FINANSIAL

DALAM LIKUIDITAS PEMBIAYAAN PERUMAHAN

Rayhan Mahatma Harikusuma ${ }^{1}$ dan Roby Syaiful Ubed $^{2}$

Gambar 1. Kebutuhan Rumah Untuk Rumah Tangga di Indonesia

\section{Kebutuhan Perumahan}

\begin{tabular}{|c|c|c|}
\hline 300.000 .000 & & \\
\hline 250.000 .000 & & \\
\hline 200.000 .000 & & \\
\hline 150.000 .000 & & \\
\hline 100.000 .000 & & \\
\hline 50.000 .000 & & \\
\hline 0 & 2010 & 2015 \\
\hline Jumlah Penduduk (Orang) & 237641326 & 255461700 \\
\hline $\begin{array}{l}\text { Jumlah Rumah Tangga } \\
\text { (Ruta) }\end{array}$ & 61390300 & 65503000 \\
\hline $\begin{array}{c}\text { Jumlah Rumah Tangga } \\
\text { Milik (Ruta) }\end{array}$ & 47884434 & 54125129 \\
\hline $\begin{array}{l}\text { Jumlah Rumah Tangga } \\
\text { Non Milik/Backlog (Ruta) }\end{array}$ & 13505866 & 11377871 \\
\hline
\end{tabular}

*Data pada tahun 2010 (Jumlah Penduduk hingga Jumlah Rumah Tangga Non Milik) berdasarkan hasil sensus penduduk yang dilakukan oleh Badan Pusat Statistik, untuk jumlah penduduk tahun 2015 didapat dari buku Proyeksi Penduduk Indonesia Tahun 2010-2035 yang selanjutnya berdasarkan data tahun 2010 diolah untuk mendapatkan jumlah rumah tangga non milik di tahun 2015

\section{Gambar 2. Peran SMF Dalam Pembiayaan Skema FLPP}

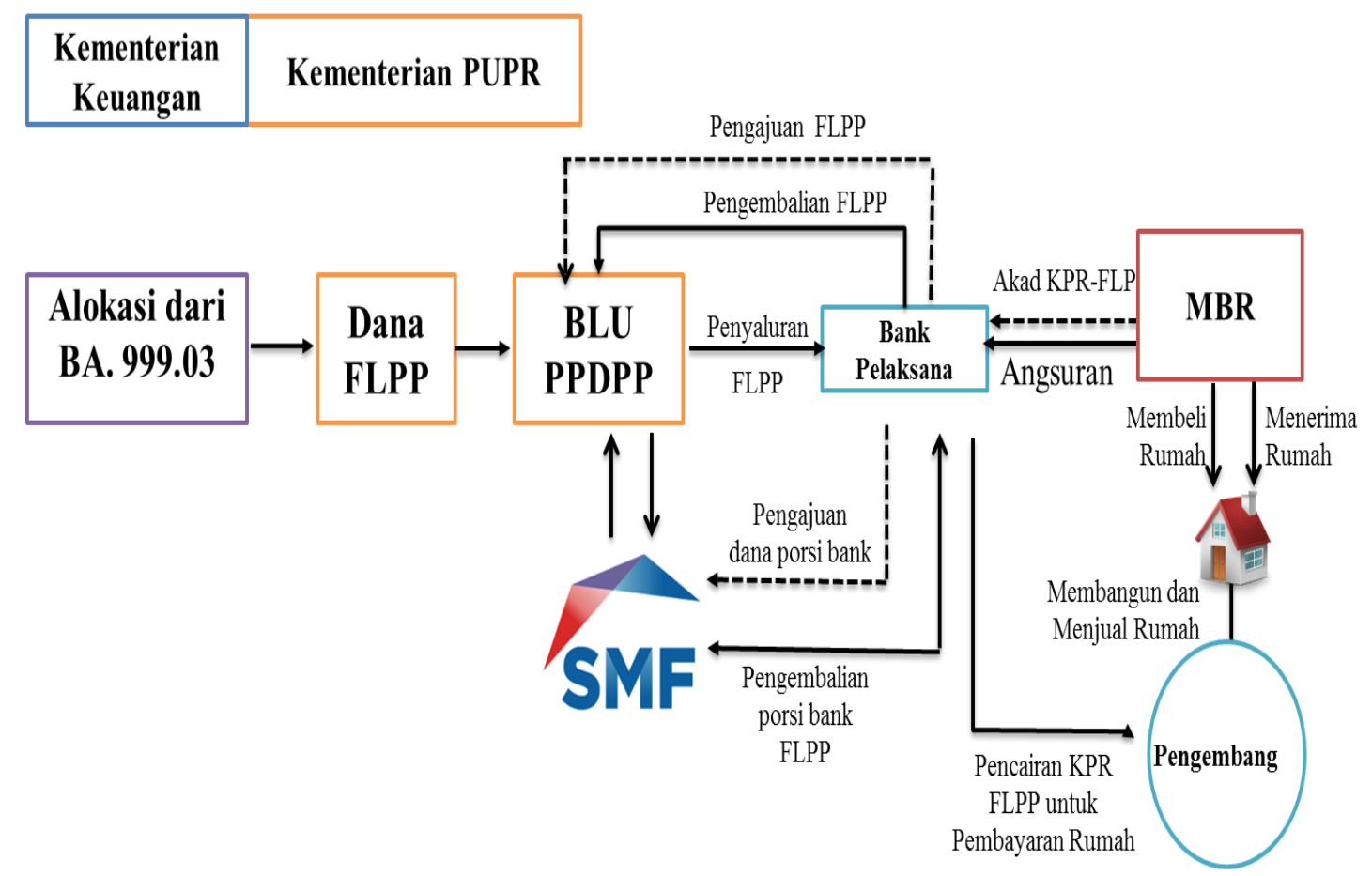


PERAN PT SARANA MULTIGRIYA FINANSIAL

DALAM LIKUIDITAS PEMBIAYAAN PERUMAHAN

Rayhan Mahatma Harikusuma ${ }^{1}$ dan Roby Syaiful Ubed $^{2}$

Gambar 3. Grafik Pertumbuhan Penyaluran Pinjaman Oleh PT Sarana Multigriya Finansial (Persero)

Dinyatakan Dalam Juta Rupiah

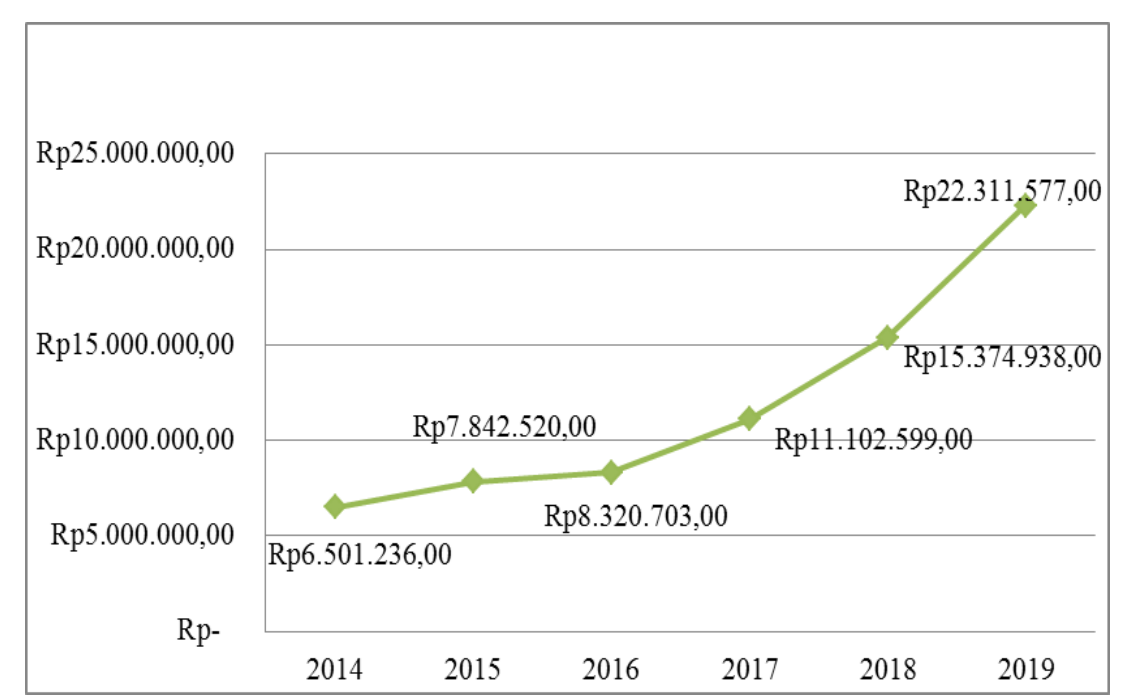

Gambar 4. Rasio Penyaluran Pinjaman Terhadap Modal Disetor

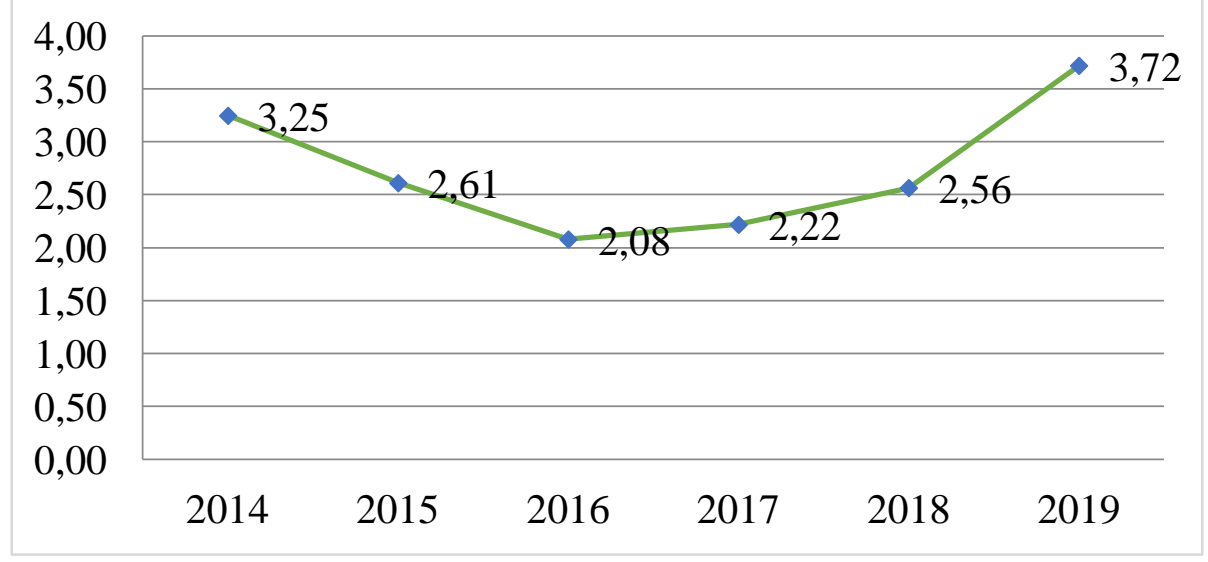

Gambar 5. Peran SMF dalam Tapera pada tahap pemanfaatan dana




Gambar 6. Peran SMF dalam Tapera Pada Tahap Pemupukan Dana

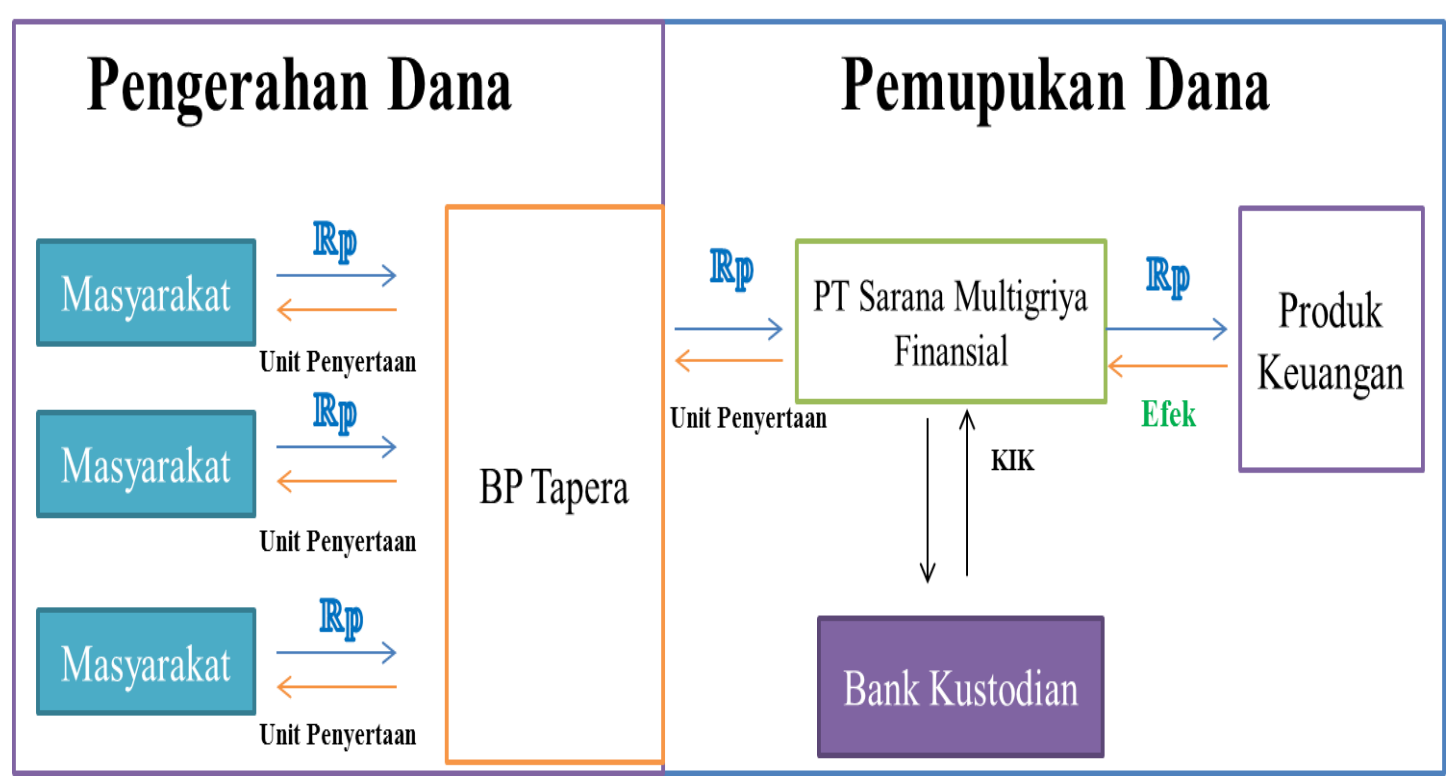

Tabel 1. Perbandingan Persentase Skema Pendanaan FLPP

\begin{tabular}{|c|c|c|}
\hline Skema Pendanaan FLPP & Bunga Pinjaman & $\begin{array}{c}\text { Persentase Keuntungan } \\
\text { Pendapatan Bersih Terhadap } \\
\text { Porsi Perbankan }\end{array}$ \\
\hline $90 \%$ Pemerintah & $9,727 \%$ & $4,644 \%$ \\
\hline $10 \%$ Perbankan & (Obligasi Korporasi) & $1,417 \%$ \\
\hline $75 \%$ Pemerintah & $4,45 \%$ & \\
\hline $25 \%$ Perbankan & (Pembiayaan SMF) & $0,683 \%$ \\
\hline $50 \%$ Pemerintah & 2,5\% & \\
\hline $50 \%$ Perbankan & (Pembiayaan SMF) & \\
\hline
\end{tabular}

